doi: $10.2478 / v 10221-011-0022-3$

\title{
In memoriam: prof. dr. Slavko Ziherl (1945-2012)
}

Slovenska psihiatrija je izgubila priznanega psihiatra, učitelja mladih strokovnjakov na področju psihiatrije in človekoljuba, ki je verjel v spoštovanje človekovih pravic in strpnost.

Prof. dr. Slavko Ziherl se je na svoji življenjski poti psihiatra zavzemal predvsem za ljudi ter seveda za napredek stroke. Mladim bodočim psihiatrom je kot predstojnik katedre za psihiatrijo na ljubljanski Medicinski fakulteti kazal smer razvoja stroke, bil je tudi njihov glavni mentor za specializacijo iz psihiatrije.

Svoje znanje je pridobival in delil tudi v tujini, predvsem na Nizozemskem, $v$ Združenih državah Amerike, v Veliki Britaniji in Kanadi. Bil je dolgoletni direktor Psihiatrične klinike v Ljubljani, predavatelj psihopatologije na Medicinski in Pravni fakulteti, predsednik Združenja psihiatrov Slovenije in podpredsednik Evropskega odbora za psihiatrijo. Svojo pot je posvetil predvsem zdravljenju alkoholizma, težavam s spolnostjo ter preprečevanjem samomorov, kot predstavnik Slovenije pa je deloval tudi $v$ mednarodnem združenju za preprečitev samomora. Kot strokovnjak na svojem področju je avtor številnih znanstvenih in strokovnih del, bil je urednik in recenzent znanstvenih del. Kot recenzent je sodeloval tudi z Univerzo na Primorskem, s Fakulteto za matematiko, naravoslovje in informacijske tehnologije.

Na ministrstvu za zdravje je v bil v letu 2008 imenovan za državnega sekretarja, vendar je sam s te funkcije odstopil, kot je povedal, zaradi nestrinjanja $z$ imenovanjem Dimitrija Rupla za posebnega odposlanca za zunanje zadeve v kabinetu predsednika vlade. Vseeno pa je na ministrstvu za zdravje svoj pečat pustil pri nekaj projektih. Zagotovo se ga bomo najbolj spominjali po vsej vloženi energiji v projekt »forenzična bolnišnica«. Bil je vodja in gonilna sila leta 2010 imenovane medresorske strokovne projektne skupine za pripravo ustanovitve in organizacije forenzične psihiatrije v Sloveniji. Tudi po njegovi zaslugi je Slovenija v letu 2011 dobila forenzično enoto $v$ UKC Maribor, s čimer so bili vzpostavljeni pogoji izvajanja dejavnosti forenzične psihiatrije na enem mestu za celotno območje Slovenije. Sama umestitev oddelka za forenzično psihiatrijo pa je hkrati tudi velik korak k destigmizaciji forenzičnopsihiatričnih pacientov, s čimer smo dokazali spoštovanje človekovih pravic in strpnost, za kar se je zavzemal tudi prof. dr. Slavko Ziherl.

Z globokim spoštovanjem,

Dorjan Marušič 